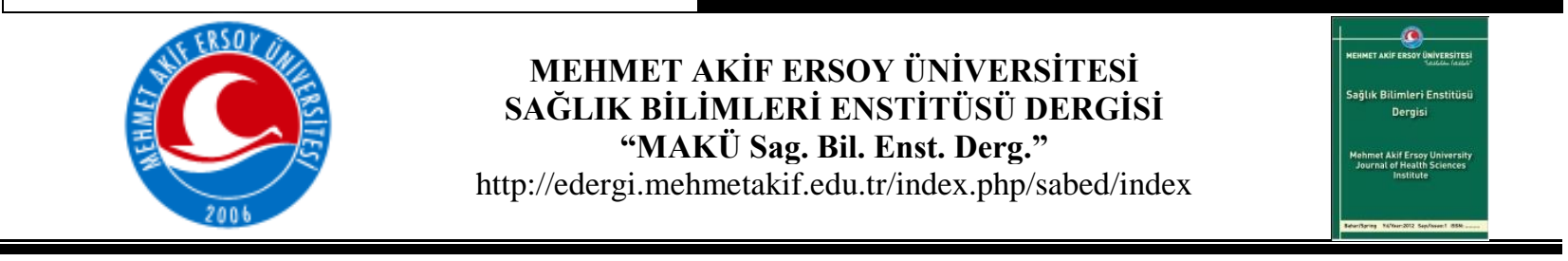

\title{
Fare Blastosistlerinde Hücre Kaderinin Belirlenmesi
}

\section{Cell Fate Determination in Mouse Blastocysts}

\author{
Cennet Sinem Çoban ${ }^{1}$, Duygu Mutluay ${ }^{2^{*}}$ \\ ${ }^{1}$ Mehmet Akif Ersoy Üniversitesi, Sağlık Bilimleri Enstitüsü, Histoloji ve Embriyoloji Anabilim Dalı, Burdur- \\ Türkiye. \\ ${ }^{2}$ Mehmet Akif Ersoy Üniversitesi, Veteriner Fakültesi, Histoloji ve Embriyoloji Anabilim Dalı, Burdur-Türkiye.
}

\begin{abstract}
Preimplantation embryonic development in mouse is culminated the blastocyst attach to the uterine wall. Blastocyst stage is critical process for the implantation and pregnancy. At E 3.5 the mouse blastocysts comprise two cell lineages: trophectoderm (TE) and inner cell mass (ICM). While the TE establishes the connection to the mother's uterus that gives rise to placenta, ICM gives rise to fetus and extraembryonic tissues. After E 3.5 blastocyst stage ICM differentiate into two distinct embryonic lineages, pluripotent epiblast (Epi) and primitive endoderm (PrE). Successful formation of these three cell lineages (TE, PrE, Epi) is crucial for embryo patterning, implantation and sustain embryonic development. Here, we review cellular and molecular mechanisms that play roles on early lineage specification in mouse embryo development. Understanding of these processes is important not only for the patients using artificial reproductive technology to achieve successful implantation and fetal development but also will be useful to find out the causes of early miscarriages and pregnancy pathologies.
\end{abstract}

Key words: Blastocyst, Mouse, Cell differentiation, Cell lineage, Preimplantation development.

Yazışma Adresi: Yrd. Doç. Dr Duygu Mutluay. Mehmet Akif Ersoy

Üniversitesi, Veteriner Fakültesi, Histoloji ve Embriyoloji Anabilim Dalı,

15030, Burdur-Türkiye.

E-posta: duygumutluay@mehmetakif.edu.tr,
Öz: Farelerde preimplantasyon embriyo gelişimi blastosistin uterus duvarına tutunması ile son bulur. Blastosist dönemi hem implantasyon hem de gebelik için kritik bir süreçtir. E 3.5 dönemindeki fare blastosistleri trofektoderm (TE) ve iç hücre kütlesi olmak üzere iki hücre soyundan oluşur. Daha sonradan plasentay1 meydana getirecek olan TE hücreleri annenin uterusu ile bağlantı kurarken ICM hücreleri fetusu ve ekstra embriyonik dokuları meydana getirir. E3.5 blastosist döneminden sonra ICM hücreleri pluripotent epiblast (Epi) ve primitif endoderm $(\mathrm{PrE})$ olmak üzere iki farklı embriyonik soya farklılaşır. Bu üç hücre soyunun (TE, PrE, Epi) başarılı bir şekilde oluşumu embriyo modellenmesi, implantasyon ve embriyonik gelişimin sürdürülebilmesi bakımından kritik bir önem taşır. Bu makalede fare embriyo gelişiminde erken soy belirlenmesinde rol oynayan hücresel ve moleküler mekanizmalar hakkında bilgiler derlenmiştir. Bu süreçlerin anlaşılması hem başarılı bir implantasyon ve fetal gelişimin sağlanması için kullanılan yardımcı üreme tekniklerinin hem de erken düşükler ve gebelikte yaşanan sorunların ortaya konulması bakımından önemlidir.

Anahtar sözcükler: Blastosist, Fare, Hücre farklılaşması, Hücre soyu, Preimplantasyon gelişimi.

Geliș Tarihi: 14.11 .2017

Kabul Tarihi: 06.12.2017

Kaynak göstermek için: Çoban C.S, Mutluay D. 2017. Fare Blastosistlerinde Hücre Kaderinin Belirlenmesi. MAKÜ Sag. Bil. Enst. Derg. 5(2): 219-227. 


\section{Giriş}

Preimplantasyon gelişimi ileri derecede farklılaşmış hücreler olan oosit ve spermatozoonun füzyonu sonucu totipotent özellikte ki zigotun oluşması ile başlar, blastosist evresindeki embriyonun annenin endometriyumuna implante olması ile son bulur (Marikawa ve ark., 2009). Bu dönem boyunca blastosistin oluşumunda etkili olan birçok hücresel ve moleküler mekanizma bulunmaktadır. Bu derleme de farelerde erken embriyonik dönemde hücre kaderinin belirlenmesi, hücre farklılaşması ve farklı hücre soylarının oluşum mekanizmaları hakkında bilgi verilecektir.

\section{Blastosist Oluşumunda Polarite Modelleri}

Farelerde embriyo gelişiminin en eski modelleri, sitoplazmik belirleyicilerin hücrenin kaderini belirlediği yönündeydi. Bununla birlikte, bu öneri, yeniden değerlendirilerek erken embriyo döneminde hücrelerin yeri değiştirildiğinde, yeni bir pozisyona getirildiğinde kaderinin değiş̧ebileceği gözlendikten sonra geçerliliğini yitirmiştir. $\mathrm{Bu}$ gözlemler araştırmacıların erken soy belirlenmesi için yeni bir model geliştirmelerine sebep olmuştur.

$\mathrm{Bu}$ iç-dış model ile sitoplazmik belirleyicilerin yerine, hücrenin kaderinin içerideki ve dışarıdaki hücre popülasyonlarının farklı olduğu, geç morula evresindeki pozisyona göre kurulduğu öne sürülmüştür. İçteki internal hücreler simetrik olarak komşu hücrelerle bağlantılı iken, diş kısımda yerleşmiş olan eksternal hücreler asimetrik olarak diğer hücrelerle de bağlantılıdır (Yamanaka ve ark., 2006).

İç-dış modelinin anlaşılabilmesi için yapılan çalışmalar hücre polarite modelinin ortaya çıkmasını sağlamıştır. Hücre polarite modeline göre hücrenin kaderi geç morula evresinden önce sekiz hücreli evrede kurulur. Sonraki hücre bölünmeleri hücrenin bölünme açısına bağlı olarak, polarite bilgisinin simetrik ve asimetrik dağılımına yol açar. Radyal (içdış) eksene paralel bölünme, polarite dağılımı ile ilgili tüm bilgileri taşıyan özdeş polarize olmuş hücreler meydana getirir. Buna karşılık, radyal eksene dik bölünme sonucu iki farklı hücre meydana gelir; bir tanesi dişta yer alıp tüm polarite bilgisine sahipken diğeri içeride konumlanmış apolar hücrelerdir. Daha sonra polar ve apolar hücreler gelişim potansiyeli olarak farklılık gösterir ve bu da TE ve ICM hücre soylarının kurulmasına sebep olur (Yamanaka ve ark., 2006). 
İç-dış model ile polarite modeli önemli bir noktada farklllık gösterir. İç-dış modelde hücrenin konumunun hücrenin kaderini belirlediği öngörülürken, hücre polarite modelinde hücrenin kaderinin hücrenin konumunu belirlediği bildirilmiştir (Yamanaka ve ark., 2006).

Hücrede polarite ilk kez kompaksiyon sırasında, çeşitli hücre altı komponentlerin hücrenin apikal kutbunda polarite oluşturması ile gözlenmiştir. Bu komponentler içinde yüzey mikrovillusları, hücre iskeleti unsurları, endozomlar ve mikrotubul organizasyon merkezleri sayılabilir (Johnson ve McConnel, 2004).

Hücre polaritesi ve hücrenin kaderi arasındaki bağlantı polarite yapıcı proteinlerin TE farklılaşmasını yönetme olasıllğı olduğunu göstermiştir. Olgun TE hücreleri polarize olmuş epitelyumun özelliklerini taşır buna örnek olarak apikal mikrovilluslar, zonula okludens ve zonula adherens gibi özel protein komplekslerin polarize olmuş dağılımını verebiliriz. Kompaksiyon öncesinde hücreler polarize olmamıştır ve mikrovilluslar hücrenin tüm yüzeyine dağılmıştır. Sekiz hücreli evrede kompaksiyon sırasında zonula adherensler apikal bölgelere toplanırlar. $\mathrm{Bu}$ sırada, hücre adezyon moleküllü olan E-kaderin ve zonula adherenslerin esas elemanları hücre-hücre bağlantı bölgelerinde yoğunlaşmaya başlar (Vestweber ve ark., 1987).

Bununla birlikte bir serin/treonin kinaz olan EMK1 (Par1) bazo-lateral olarak lokalize olur (Vinot ve ark., 2005). Ayrıca bu dönemde Par3, Par6 ve atipik PKCs (aPKCs) gibi bazı proteinler apikal hücre korteksinde küçük bir alanda lokalize olurlar (Pauken ve Capco, 2000; Plusa ve ark., 2005; Thomas ve ark., 2004; Vinot ve ark., 2005). Geç morula döneminde zonula okludensler, zonula adherenslere apikal olacak şekilde toplanmaya başlarlar. $\mathrm{Bu}$ sırada birçok apikal protein zonula okludensler etrafında lokalize olur (Mutluay ve Öner, 2015; Vinot ve ark., 2005). Par3, Par6 ve aPKC apikal protein kompleksi oluştururlar (Etienne-Manneville ve Hall, 2003). Bu kompleksin oluşumu mikrotübül organizasyonunu kontrol eder ve Lethal giant larvae ( $\mathrm{Lgl})$ gibi bazo-lateral proteinleri aPKC aracılı fosforilasyonu yöneterek apikal membranın dışında tutar (Plant ve ark., 2003; Yamanaka ve ark., 2003). 


\section{Blastosist Oluşumu ve Etkili Olan Mekanizmalar}

Embriyoda gerçekleşen beşinci bölünmeden sonra blastomerler arasında bir veya daha fazla kavite oluşmaya başlar. Boşluklar daha sonra genişler ve birbirleriyle kaynaşarak tek bir büyük kavite oluştururlar. Bu noktada embriyo, özel bir isim alarak "blastosist" olarak adlandırılır (Marikawa ve Alarcon, 2009).

Plasentalı memelilerde preimplantasyon gelişiminde, erken konseptus fetal gelişimi ve hayatta kalmayı destekleyecek ekstraembriyonik dokular meydana getirir. Ortaya çıkacak ilk embriyonik doku blastosistin diş epitelyal katmanı oluşturan trofoektoderm'dir ve iç hücre kütlesi adı verilen blastosistin kavitesine bakan hücrelerden oluşan, fetüsü meydana getiren pluripotent iç hücre kütlesinden ayrılır (Marikawa ve Alarcon, 2012). Blastosistin uterus duvarına implantasyonuna aracılık eden aynı zamanda plasentasyona katkıda bulunan TE, trofoblastların progenitörüdür. Apikal bazal hücre polarite düzenleyicileri ve Hippo sinyal yolakları, TE epitelizasyonu ve Cdx2 gibi TE spesifik transkripsiyon faktörlerinin aktivasyonundan sorumludur. $\mathrm{Cdx} 2$, kaudal-tip homeodomain transkripsiyon faktörü pluripotensinin anahtar düzenleyicisi olan POU-domain transkripsiyon faktörü Pou5fl'in ekspresyonunu baskılar ve bu durum sonrasında TE soyunun ICM'den ayrılmasını destekler (Laeno ve ark., 2013). Yapılan çalışmalarda Cdx2'nin TE’nin varlığını sürdürebilmesi açısından esansiyel iken, ICM'nin oluşumu ve varlığını sürdürebilmesi için easansiyel olmadığ1 görülmüştür. E3.5 blastosist döneminde, Oct4 (Pou5f1) transkripsiyon faktörü az oranda TE hücrelerinden, güçlü şekilde ise ICM hücrelerinden eksprese edilir (Okamoto ve ark., 1990; Rosner ve ark., 1990; Schöler ve ark., 1990). Oct4'un ekspresyonu E3.5 döneminden sonra sadece ICM hücreleri ile sınırlanır (Dietrich ve Hiiragi, 2007). Pou5f1'den yoksun olan embriyoların, TE makerları eksprese eden ICM meydana getirdiği görülmüştür (Ralston ve ark., 2010). Oct4'un tersine Cdx2, E3.5 döneminde spesifik olarak yanlızca TE hücrelerinden eksprese edilmektedir (Dietrich ve Hiiragi, 2007; Niwa ve ark., 2005; Ralston ve ark., 2010).Yapılan bir çalışma da Cdx2'nin yoksunluğunun, TE hücrelerinde ICM markerlarının ektopik ekspresyonu ve TE gelişimini sürdürmede yetersizlik meydana gelmesine neden olduğu bildirilmiştir (Strumpf ve ark., 2005). Cdx2 ekspresyonunun TE hücreleri ile erken dönemde sınırlanması TE içerisindeki ICM-spesifik transkripsiyon faktörlerin ekspresyonunu inhibe etme rolü ile ilişkili olduğu düşünülmektedir. Bu durum Cdx2'nin TE ve ICM soylarının ayrılmasında esansiyel bir faktör olduğunu göstermektedir. Cdx2 ekspresyonu kendi başına TEAD ailesi transkripsiyon 
faktörü Tead4 ile onun yardımcı-aktivatör ortağı olan Yap (Yap1tarafından kodlanan) ile düzenlenir (Masui ve ark., 2007; Nishioka ve ark., 2009). Tead4 preimplantasyon dönemi embriyolarının tüm hücrelerinde eksprese edilirken, Yap gelişen TE hücreleri ile sınırlıdır. Böylece Cdx2 ekspresyonunu bu diş hücrelerle sınırlı tutar. Yap'ın nükleer lokalizasyonunun fosforilasyon ve sitoplazmik ayrılmasının Hippo yolak üyesi Lats2 aracılığı ile düzenlendiği gösterilmiştir (Nishioka ve ark., 2009).

Yapılan bir çalışma Hippo sinyal yolak komponentleri olan Tead4, onun yardımcı aktivatör proteinleri olan Yap ve Taz (Wwtr1) ve protein kinazlardan Lats1/2 'nin hücre kaderinin özelleşmesinde kritik rol oynadıklarını ortaya koymuştur. İç hücrelerde hücrehücre adezyonları Hippo sinyal verimini aktive ederken Yap'ın çekirdeğe toplanmasını baskılayarak Tead4'ü inaktive eder. Bu aktivasyon sonucunda Tead4-Yap kompleksi, hücrelerin TE’e farklılaşmasını destekleyen transkripsiyon faktörleri olan Cdx2 ve Gata3'ü uyarır (Hirate ve ark., 2012; Hirate ve ark., 2013; Masui ve ark., 2007; Niakan ve ark., 2010; Ralston ve ark., 2010). Bu yüzden iç-dış modeli destekleyen diferansiyel hücre kaderi spesifikasyonu sırasında pozisyon-bağımlı Hippo sinyalizasyonun kurulması kritik bir adım olarak değerlendirilmektedir (Hirate ve ark., 2012; Hirate ve ark., 2013; Masui ve ark., 2007; Nishioka ve ark., 2009).

Son yıllarda yapılan birçok çalışma TE gelişimi sırasında görülen hücre polaritesinin önemli olduğunu vurgulamıştır. Par-aPKC sistemi hücrelerin apikobazal polaritesinin düzenlenmesinde esas bir rol oynamaktadır. Pard6b'nin knockdown'u sonucunda Cdx2 'nin ekspresyonunun azaldığı fonksiyonel TE oluşumunda başarısızlık meydana geldiği

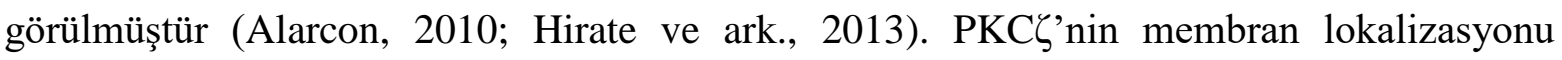
Yap'in nükleer yoğunlaşması ve Cdx2'nin ekspresyonu ile ilişkili iken E kaderin'in tamamen yokluğunda hücre polarizasyonunun bozulduğu görülmüştür (Alarcon ve Marikawa, 2003; Stephenson ve ark., 2010). Tüm bu çalışmalar preimplantasyon dönemi embriyolarında hücre kaderinin belirlenmesi ve Hippo sinyalizasyonunun düzenlenmesinde hücre polaritesinin önemli olabileceğini göstermiştir.

Embriyoda meydana gelen ikinci embriyonik doku ise ICM'den meydana gelen primitif endoderm (PrE)'dir. E3.5 ile E 4.5 embriyonik günleri arasında blastosist kavitesi genişlemeye devam eder. $\mathrm{Bu}$ sırada $\operatorname{PrE}$ de bulunan hücre öncüllerinin karışımı ve pluripotent epiblast (Epi) ICM'de belirmeye başlar (Chazaud ve ark., 2006; Laeno ve ark., 2013; Meilhac ve ark., 2009; Plusa ve ark., 2008). E4.5 embriyonik dönemde ise $\operatorname{PrE}$ 
Epi'den tam olarak ayrılır ve ICM'in blastosist kaviesine bakan süperfisial katmanını oluşturur. Blastosistin implantasyondan sonra PrE vitellüs kesesine katkıda bulunacak olan viseral ve parietal endodermi meydana getirir. PrE endoderm aynı zamanda Epi'den meydana gelen dokularda vücut ekseninin belirlenmesinde kritik roller üstlenir. Yapılan çalışmalar E4.5 dönemindeki blastosistin ICM hücreleri işaretlendiğinde bu hücrelerin ya Epi ya PrE ancak her iki hücre katmanın oluşumuna birden katkı yapmadıklarını ortaya koymuştur. Bu sonuç Epi ve PrE hücrelerinin diğer hücrelere oranla daha erken dönemde kalıtıldığını ancak daha sonra ilgili tabakalara ayrıldığını göstermiştir (Chazaud ve ark., 2006; Plusa ve ark., 2008). Epi embriyoyu oluşturacak birçok hücreyi meydana getirmesinin yanı sıra amniyon, allantois ve viseral vitellüs kesesini çevreleyen ekstraembriyonik mezoderm hücrelerini meydana getirir (Artus ve ark., 2011; Laeno ve ark., 2013; Mutluay, 2016; Rossant, 2004).

PrE hücreleri, PrE farklılaşması için esansiyel olan zinc finger transkripsiyon faktörleri Gata bağlayıcı protein ve 4 ve 6 (Gata4, Gata6)'yı eksprese etmektedir (Cai ve ark., 2008; Fujikura ve ark., 2002; Laeno ve ark., 2013; Wang ve ark., 2011). Epi hücreleri ise fare epiblast hücreleri ve embriyonik kök hücrelerinde pluripotensinin ve kendini yenilemenin devamı için esansiyel olan homeobox transkripsiyon faktörü, Nanog'u eksprese ederler (Niakan ve ark., 2010). Yapılan çalışmalar soy spesifik faktörler olan Gata4 ve Sox17'nin ekspresyonun PrE ile sınırlı olduğu Nanog'un ekspresyonun ise Epi hücreleri ile sınırlı olduğunu göstermiştir (Mutluay, 2016; Yamanaka ve ark., 2006).

\section{Blastosistin Kaderinin Belirlenmesi}

Blastosist dönemi embriyolarda morfogenezisin mekanizması ve modellenmesi (patterning) konusunda yapılan çalışmalar sonucunda üç model önerilmiştir ancak kabul edilmiş kesin bir model bulunmamaktadır. Ön-modelleme olarak isimlendirilen modelde blastosist modellemesi ve morfogenezisi ile bilginin yumurta döneminde zaten bulunduğu yönündedir (Gardner, 2007; Gardner ve Davies, 2003; Zernicka-Goetz, 2002). 4 hücreli evredeki blastomerlerde farklı gelişim potansiyellerine bağlı olarak epigenetik bir mekanizma yolu ile belirli yarıklanma modelleri kurulabilir. Ancak şimdiye kadar blastosistte meydana gelen soy ayrımı ile yumurtanın moleküler organizasyonu ile ilgili tanımlanmış bir bilgi bulunmamaktadır. İkinci olarak düzenleyici model blastomerler arasındaki farklılığın ve soy dağılımı ile ilgili durumun kompaksiyondan sonra (8 hücreli) meydana geldiği öngörülmektedir (Johnson ve McConnel, 2004). Ayrıca TE ve ICM 
hücrelerinde blastomerlerin pozisyonunu temel alan (iç-dış model) belirlendiği öne sürülmüştür (Tarkowaki ve Wroblewska, 1967). Yukarıda da açıklandığı gibi bu modele göre diştaki hücreler TE hücrelerini meydan getirirken içteki hücreler ICM hücrelerin meydana getirir (Johnson ve Ziomek, 1981; Plusa ve ark., 2005; Vinot ve ark., 2005). Blastosist morfogenezisinin önceden belirlenmediği düşüncesi düzenleyici modeli desteklemektedir (Alarcon ve Marikawa, 2003; Motosugi ve ark., 2005). Üçüncü olarak preformasyon modeli olarak adlandırılan model de yarıklanma modelleri blastosist içindeki hücrelerin gelecekteki dağımını böylece de kaderini etkilediği önerilmiştir (Graham, 1971). İki hücreli evredeki her iki blastomer de morula ve blastosist döneminde dış ve içteki hücre popülasyonuna katkıda bulunmasına rağmen daha önceden bölünen hücrenin soyundan gelen hücrenin iç tarafta da lokalize olduğu gözlemlenmiştir $\mathrm{Bu}$ modelin diğer iki model arasında köprü görevi gördüğ̈̈ belirtilmiştir (Surani ve Berton, 1984).

\section{Sonuç}

Memeliler içerisinde erken embriyo gelişimi ve soy belirlenmesi ve ayrılması üzerine en çok çalışılan hayvan farelerdir. Preimplantasyon döneminde yer alan hücre soylarının meydana gelmesinde esansiyel olan hücresel ve moleküler mekanizmaların bilinmesi son yıllarda tüm dünyada daha sıklıkla kullanılan yardımcı üreme yöntemlerinin iyileştirilmesine yardımcı olacaktır. Aynı zaman da insanlarda erken düşüklerin ve erken gebelik patolojilerinin nedenlerinin anlaşılmasına ışık tutacaktır.

\section{Kaynaklar}

1. Alarcon VB. 2010. Cell Polarity Regulator PARD6B Is Essential for Trophectoderm Formation in the Preimplantation Mouse Embryo 1. Biology of reproduction. 83: 347358 .

2. Alarcon VB, Marikawa Y. 2003. Deviation of the blastocyst axis from the first cleavage plane does not affect the quality of mouse postimplantation development. Biology of reproduction. 69: 1208-1212.

3. Artus J, Piliszek A, Hadjantonakis AK. 2011. The primitive endoderm lineage of the mouse blastocyst: Sequential transcription factor activation and regulation of differentiation by

ISSN: 2148-2837
Sox17. Developmental biology. 350: 393404.

4. Cai KQ, Capo-Chichi CD, Rula ME, ve ark. 2008. Dynamic GATA6 expression in primitive endoderm formation and maturation in early mouse embryogenesis. Developmental Dynamics. 237: 2820-2829.

5. Chazaud C, Yamanaka Y, Pawson T, ve ark. 2006. Early lineage segregation between epiblast and primitive endoderm in mouse blastocysts through the Grb2-MAPK pathway. Dev. Cell. 10: 615-624. 
6. Dietrich JE, Hiiragi T. 2007. Stochastic patterning in the mouse preimplantation embryo. Development. 134: 4219-4231.

7. Etienne-Manneville S, Hall A. 2003. Cell polarity: Par6, aPKC and cytoskeletal crosstalk. Curr Opn Cell Biol. 15: 67-72.

8. Fujikura J, Yamato E, Yonemura S, ve ark. 2002. Differentiation of embryonic stem cells is induced by GATA factors. Genes \& development. 16: 784-789.

9. Gardner RL. 2007. The axis of polarity of the mouse blastocyst is specified before blastulation and independently of the zona pellucida. Hum. Reprod. 22: 798-806.

10. Gardner RL, Davies TJ. 2003. The basis. and significance of prepatterning in mammals. Philos. Trans. R. Soc. Lond. B Biol. Sci. 358: 1331-1338.

11. Graham CF. 1971. The design of the mouse blastocyst. In Symposia of the Society for Experimental Biology. 25: 371-378.

12. Hirate $\mathrm{Y}$, Cockburn $\mathrm{K}$, Rossant $\mathrm{J}$, ve ark. 2012. Tead4 is constitutively nuclear, while nuclear vs. cytoplasmic Yap distribution is regulated in preimplantation mouse embryos. Proceedings of the National Academy of Sciences. 109: 3389-3390.

13. Hirate Y, Hirahara S, Inoue KI, ve ark. 2013. Polarity-dependent distribution of angiomotin localizes Hippo signaling in preimplantation embryos. Current Biology. 23: 1181-1194.

14. Johnson MH, McConnell JM. 2004. Lineage allocation and cell polarity during mouse embryogenesis. Semin Cell Dev Biol. 15: 583-597.

15. Johnson MH, Ziomek CA. 1981. The foundation of two distinct cell lineages with in the mouse morula. Cell 24: 71-80.

16. Laeno AMA, Tamashiro DAA, Alarcon VB. 2013. Rho-Associated Kinase Activity Is Required for Proper Morphogenesis of the Inner Cell Mass in the Mouse Blastocyst. Biol. Reprod. 89: 122.

17. Marikawa Y, Alarcon VB. 2012. Creation of Trophectoderm, the First epithelium, in Mouse Preimplantation Development. Results Probl Cell Differ. 55: 165-84.
18. Marikawa Y, Alarcon VB. 2009. Establishment of trophectoderm and inner cell mass lineages in the mouse embryo. Mol Reprod Dev., 76, 1019-32.

19. Masui S, Nakatake $Y$, Toyooka $Y$, ve ark. 2007. Pluripotency governed by Sox 2 via regulation of Oct3/4 expression in mouse embryonic stem cells. Nature cell biology, 9: 625-635.

20. Meilhac SM, Adams RJ, Morris SA, ve ark. 2009. Active cell movements coupled to positional induction are involved in lineage segregation in the mouse blastocyst. Dev Biol. 331: 210-221.

21. Motosugi N, Bauer T, Polanski Z, ve ark. 2005. Polarity of the mouse embryo is established at blastocyst and is not prepatterned. Genes \& development. 19: 1081-1092.

22. Mutluay D. 2016. Distribution of Primitive Endoderm and Epiblast Lineage Specific Factors in Late Stage Blastocysts. Slovenian Veterinary Research. 53: 4.

23. Mutluay D, Öner H. 2015. Farelerde Preimplantasyon Döneminde Trofoektoderm ve İç Hücre Kütlesinin Oluşumu. Mehmet Akif Ersoy Üniversitesi Sağlık Bilimleri Enstitüsü Dergisi. 3: 1-9.

24. Niakan KK, Ji H, Maehr R, Vokes SA, Rodolfa KT, Sherwood RI, McMahon AP. 2010. Sox17 promotes differentiation in mouse embryonic stem cells by directly regulating extraembryonic gene expression and indirectly antagonizing selfrenewal. Genes \& development. 24: 312-326.

25. Nishioka $\mathrm{N}$, Inoue $\mathrm{KI}$, Adachi $\mathrm{K}$, ve ark. 2009. The Hippo signaling pathway components Lats and Yap pattern Tead4 activity to distinguish mouse trophectoderm from inner cell mass. Developmental cell. 16: 398-410.

26. Niwa H, Toyooka $Y$, Shimosato $D$, ve ark. 2005. Interaction between Oct $3 / 4$ and $\mathrm{Cdx} 2$ determines differentiation. Cell. 123: 917-929.

27. Okamoto K, Okazawa H, Okuda A, ve ark. 1990. A novel octamer binding transcription factor is differentially expressed in mouse embryonic cells. Cell. 60: 461-472. 
28. Pauken CM, Capco DG. 2000. The expression and stage-specific localization of protein kinase $\mathrm{C}$ isotypes Mouse preimplantation development. Dev Biol. 223: 411-421.

29. Plant PJ, Fawcett JP, Lin DC, ve ark. 2003. A polarity complex of mPar-6 and atypical PKC binds, phosphorylates and regulates mammalian Lgl. Nat Cell Biol. 5: 301-308.

30. Plusa B, Frankenberg S, Chalmers A, ve ark. 2005. Downregulation of Par3 and aPKC function directs cells towards the ICM in the preimplantation mouse embryo. Journal of cell science. 118: 505-515.

31. Plusa B, Hadjantonakis AK, Gray D, ve ark. 2005. The first cleavage of the mouse zygote predicts the blastocyst axis. Nature. 434: 391395.

32. Plusa B, Piliszek A, Frankenberg S, ve ark. 2008. Distinct sequential cell behaviours direct primitive endoderm formation in the mouse blastocyst. Development. 135: 3081-3091.

33. Ralston A, Cox BJ, Nishioka N, ve ark. 2010. Gata3 regulates trophoblast development downstream of Tead4 and in parallel to Cdx2. Development. 137: 395-403.

34. Ralston A, Rossant J. 2008. Cdx2 acts downstream of cell polarization to cellautonomously promote trophectoderm fate in the early mouse embryo. Developmental biology. 313: 614-629.

35. Rosner $\mathrm{MH}$, Vigano MA, Ozato $\mathrm{K}$, ve ark. 1990. A POU-domain transcription factor in early stem cells and germ cells of the mammalian embryo. Nature. 345: 686-692.

36. Rossant J. 2004. Lineage development and polar asymmetries in the peri-implantation mouse blastocyst. In Seminars in cell \& developmental biology. 15: 573-581.

37. Schöler HR, Ruppert S, Suzuki N, ve ark. 1990. New type of POU domain in germ linespecific protein Oct-4. Nature. 344: 435-439.

38. Stephenson RO, Yamanaka Y, Rossant J. 2010. Disorganized epithelial polarity and excess trophectoderm cell fate in preimplantation embryos lacking Ecadherin. Development. 137: 3383-3391.

39. Strumpf D, Mao CA, Yamanaka $Y$, ve ark. 2005. $\mathrm{Cdx} 2$ is required for correct cell fate specification and differentiation of trophectoderm in the mouse blastocyst. Development. 132: 2093-2102.

40. Surani MAH, Barton SC. 1984. Spatial distribution of blastomeres is dependent on cell division order and interactions in mouse morulae. Developmental biology. 102: $335-$ 343.

41. Tarkowski AK, Wroblewska J. 1967. Development of blastomeres of mouse eggs isolated at the 4-and 8-cell stage. Development. 18: 155-180.

42. Thomas FC, Sheth B, Eckert JJ, Bazzoni G, Dejana E, Fleming TP. 2004. Contribution of JAM-1 to epithelial differentiation and tightjunction biogenesis in the mouse preimplantation embryo. J Cell Sci. 117: 55995608.

43. Vestweber D, Gossler A, Boller $\mathrm{K}$, ve ark. 1987. Expression and distribution of cell adhesion molecule uvomorulin in mouse preimplantation embryos. Developmental biology. 124: 451-456.

44. Vinot S, Le T, Ohno S, ve ark. 2005. Asymmetric distribution of PAR proteins in the mouse embryo begins at the 8-cell stage during compaction. Developmental biology. 282: 307319.

45. Wang Y, Smedberg JL, Cai KQ, ve ark. 2011. Ectopic expression of GATA6 bypasses requirement for Grb2 in primitive endoderm formation. Developmental Dynamics. 240: 566-576.

46. Yamanaka T, Horikoshi $\mathrm{Y}$, Sugiyama $\mathrm{Y}$, ve ark. 2003. Mammalian $\mathrm{Lgl}$ forms a protein complex with PAR-6 and aPKC independently of PAR-3 to regulate epithelial cell polarity. Current biology. 13: 734-743.

47. Yamanaka Y, Ralston A, Stephenson RO, ve ark. 2006. Cell and Moleculer Regulation of the Mouse Blastocyst. Developmental Dynamics. 235: 2301-2314.

48. Zernicka-Goetz M. 2002. Patterning of the embryo: the first spatial decisions in the life of a mouse. Development. 129: 815-829. 